\title{
J Sloth-Nielsen
}

\section{The Jurisdiction of the Regional Courts Amendment Act, 2008: Some implications for child law and divorce jurisdiction}

\begin{abstract}
Summary
The promulgation of the Jurisdiction of the Regional Courts Amendment Act, 31 of 2008 (hereafter the JRCAA) in 62 large urban magisterial districts on 9 August 2010 (Women's Day) heralds a potentially drastic transformation of the practice of civil procedure in South Africa. This article focuses on its implications for family law and, especially, child law proceedings. The various dimensions of jurisdictional reform are first explained with reference to the Children's Act 38 of 2005 and the JRCAA, whereafter their import is analysed. It will be questioned whether the provisions of the JRCAA were drafted with sufficient care, and why no reference was made to the provisions of the Children's Act 38 of 2005. The potential difficulties occasioned by the new jurisdictional rules will be described. In conclusion, comments are made about the positive and less positive aspects of the JRCAA, and suggestions for reform are provided.
\end{abstract}

\section{Die Jurisdiction of the Regional Courts Amendment Act, 2008:} Gevolge vir kinderreg en egskeiding jurisdiksie

\begin{abstract}
Die inwerkingtreding van die Jurisdiction of Regional Courts Amendment Act, 31 van 2008 (voortaan die JRCAA), in 62 groot stedelike landdrosdistrikte op 9 Augustus 2010 (Vrouedag), het die potensiaal vir drastiese transformasie van die praktyk van siviele prosesreg in Suid-Afrika. Hierdie artikel fokus op die implikasies van die Wet vir familiereg, en in besonder, kindderreg verrigtinge. Die verskillende afmetings van die jurisdiksionele hervormings word eerstens beskryf met verwysing na die Kinderwet, 38 van 2005 en die JRCAA, waarna hulle mening geanaliseer word. Dit word bevraagteken of die JRCAA bepalings met genoeg sorg geformuleer was, en hoekom geen verwysing na die Kinderwet verskyn. Die moontlike probleem wat die nuwe jurisdiksionele bepalings mag veroorsaak word beskryf. Gevolglik word daar kommentaar gelewer oor die positiewe and minder positiewe aspekte van die JRCAA, en voorstelle vir hervorming word aanbeveel.
\end{abstract}




\section{Introduction}

The promulgation of the Jurisdiction of the Regional Courts Amendment Act, 31 of 2008 (hereafter the JRCAA) in 62 large urban magisterial districts on 9 August 2010 (Women's Day) heralds a potentially drastic transformation of the practice of civil procedure in South Africa. It has also explicitly been enacted as part of the various efforts to transform the judiciary and the practice of law in South Africa. ${ }^{1}$ This is because the Act first seeks to imbue Regional Courts, which hitherto have enjoyed only criminal jurisdiction, with civil jurisdiction, thereby equipping presiding officers in these courts to 'compete' with practitioners from private practice for judicial appointment, since Regional Court magistrates will presumably in future have acquired the necessary civil court experience to be eligible for judicial appointment. ${ }^{2}$

However, this article focuses on the second stated objective of the JRCAA, namely to further access to justice by rendering High Court applications justiciable in Regional Courts. For the present discussion, the focus is on family law and, especially, child law proceedings. The various dimensions of jurisdictional reform are first explained with reference to the Children's Act 38 of 2005 and the JRCAA, whereafter their import is analysed. It will be questioned whether the provisions of the JRCAA were drafted with sufficient care, and why no reference was made to the provisions of the Children's Act 38 of 2005. The potential difficulties occasioned by the new jurisdictional rules will be described. In conclusion, comments are made about the positive and less positive aspects of the JRCAA, and suggestions for reform are provided.

\section{Background to the Family Court pilot projects and the development of the jurisdictional provisions of the Children's Act 38 of 2005}

Jurisdiction was a highly contested feature of the development of the Children's Act. The intention of the South African Law Reform Commission (hereafter SALRC) was to broaden access to justice, without unduly compromising expertise, or treating all matters as equally complex. Much of the SALRC's investigation was undertaken at a very fluid time in the history of child and family law developments. It will be recalled that the pilot Family Court programme had been initiated in the latter part of the 1990s, overtly to deal with the need to deracialise the old 'black divorce' courts. ${ }^{3}$ The pilot Family Courts were instituted in six magisterial districts in late $1998,{ }^{4}$ and enjoyed the same geographical jurisdiction of the former 'black divorce' courts, i.e. as established under

1 At the time of writing, the Legal Practice Bill 2010 still awaits parliamentary debate after originally being tabled in 2000.

2 This is explicitly detailed in the Preamble setting out the purposes of the Amendment Act, viz. "to promote the development of judicial expertise among the ranks of magistrates with the view to broadening the pool of fit and proper persons qualifying for appointment to the superior courts".

3 Budlender 1998; Burman et al. 2000.

4 Budlender 1998. 
the Black Administration Act 9 of 1929. This jurisdiction had not in any way been similar to the geographical jurisdiction of the Regional Courts, instead being divided into circuits (Southern Divorce Court, North Eastern Divorce Court, and the Central Divorce Court) which crossed provinces, and dealt with the resolution of matters arising from customary law disputes. ${ }^{5}$ The pilot Family Courts adopted the same geographical jurisdiction as the former black divorce courts; in some areas, related family law courts were 'clustered' in an attempt to provide a more coherent family law service. Examples included maintenance courts and courts dealing with domestic violence, which were situated in close proximity to the new pilot Family Courts.

Despite what seemed to be a promising start towards a unified family court jurisdiction to be tested in the pilot Family Courts, without clear direction or resources from the Department of Justice and Constitutional Development, they soon became marginalised from broader family and child law trends. Early academic studies ceased, and practitioner interest and support dwindled as the understaffed and, in their view, inexperienced, personnel struggled to deal with family law practice for the poor family law litigants who could not afford the more pricy justice of the High Courts, or who were not prepared to wait lengthy periods for trials in High Courts.

At the same time, a 'proper' Family Court was under discussion. A Family Court Task team was established, and this team met for some years before it disappeared when it lost the political goodwill of the Department. Rules of procedure, which were expected, a blueprint for family court specialisation, which was rumoured to be under development, and the rewriting of the Divorce Act did not occur, although these had been mooted during the life of the Family Court Task team. ${ }^{6}$ All these practice developments were occurring while the review of the Child Care Act 74 of 1983 was underway, as described next.

A Project Committee of the SALRC had been established to effect the review of the Child Care Act in 1997, and after releasing an Issue Paper in 1998, in which the scope of the investigation was set out, the Project Committee completed the major Discussion Paper on the Review of the Children's Act in 2000. The uncertainty concerning the future of family courts, and jurisdiction in the sphere of family law, in general, left the SALRC unclear as to how to proceed for much of the tenure of the Project Committee. Ultimately, it became clear that a well-resourced and expert family court model was not going to emerge from other quarters, and that the SALRC would have to forge ahead and propose its own blueprint for those aspects of family law which fell within its mandate, i.e. the law relating to children.

Indeed, the uncertainty that had prevailed is evident throughout various parts of the Children's Act 38 of 2005 that has now been adopted, insofar as the Act periodically refers to 'a divorce court', which at the time was a nonexistent legal entity. In this regard the following sections can be cited:

5 Skelton 2009; Carnelly et al. 2010:337.

6 Chaskalson and De Jong 2002. 
Section 22(4)(b) - Subject to subsection (6), a parental responsibilities and rights agreement takes effect only if (a) registered with the family advocate; or (b) made an order of the High Court, a divorce court in a divorce matter or the children's court on application by the parties to the agreement.

Section 23(1) - Any person having an interest in the care, well-being or development of a child may apply to the High Court, a divorce court in divorce matters or the children's court for an order granting to the applicant, on such conditions as the court may deem necessary - (a) contact with the child; or (b) care of the child.

Section 28(1) - A person referred to in subsection (3) may apply to the High Court, a divorce court in a divorce matter or a children's court for an order- (a) suspending for a period, or terminating, any or all of the parental responsibilities and rights which a specific person has in respect of a child; or (b) extending or circumscribing the exercise by that person of any or all of the parental responsibilities and rights that person has in respect of a child.

Section 29(1) - An application in terms of section 22 (4) (b), 23, 24, 26 (1) (b) or 28 may be brought before the High Court, a divorce court in a divorce matter or a children's court, as the case may be, within whose area of jurisdiction the child concerned is ordinarily resident.

Section 45(3) - pending the establishment of Family Courts by an Act of Parliament, High Courts and Divorce courts ${ }^{7}$ have exclusive jurisdiction in the listed matters. ${ }^{8}$

The words 'divorce court' were also expressly defined in section 1 of the Children's Act as "the divorce court established in terms of section 10 of the Administration Amendment Act, 1929 (Act 9 of 1929)."

Due to the prevailing uncertain future direction, the SALRC initially proposed a model which can really be described as an interim solution. Divorce, division of matrimonial property, and spousal maintenance fell, naturally, outside the mandate of this specific investigation. Therefore, the proposals were confined to those aspects of child law that could be 'divorced' from divorce.

Whereas the Child Care Act 74 of 1983 had provided for children's courts to be based at district court level (and every magistrate's court was designated also as a children's court), the SALRC model suggested the introduction of a two-tier system of 'child and family courts', to be located at both magisterial

7 In this section, 'Divorce Courts' are spelt with a capital letter in the text of the Children's Act.

8 The listed matters relate to "the guardianship of the child; the assignment, exercise, extension, restriction, suspension or termination of guardianship in respect of a child; artificial insemination; the departure, removal or abduction of a child from the Republic; applications requiring the return of a child to the Republic from abroad; the age of majority or the contractual or legal capacity of a child; the safeguarding of a child's interest in property; and surrogate motherhood." 
and regional court level. ${ }^{9}$ It was clarified that the children's court would be a court at district level, in view of its accessibility (geographically and financially) to Joe Public, and in view of the existing infrastructure at magisterial district level, not to mention the historical role that children's courts at every magisterial district have played since their introduction in 1937.

However, the idea of a role for the court at the second (superior) level was novel. It was proposed that jurisdiction at this secondary level would be reserved for more complex matters, as well as for appeals from the lower courts. The court at second level, to be called a child and family regional court, would mirror the geographical jurisdiction of the regional (criminal) courts, but with exclusive (civil) jurisdiction conferred by the proposed Children's Act. In time, this court could become the specialised family court that had initially been proposed by the Hoexter Commission of Inquiry into the Structure and Functioning of the Courts in the 1980s. As regards the choice of first or second tier court as a court of first instance, it was proposed that a sifting process, to be fulfilled by admission clerks, would ensure that more complex matters entered the system at the second level as matters of first instance - a modified form of specialised Regional Court dedicated to child law matters and that less complex matters would be channelled to the children's courts at magistrate's court level in the first instance. In addition, it was proposed that the present jurisdiction of the High Courts in matters relating to child law (including guardianship and all other dimensions of parental rights and responsibilities) be abrogated altogether: that is, the High Court would not be a competent court of first instance in any matter related to children, including guardianship. This was intentional: the High Court's singular expertise as 'upper guardians' of all children within their area of jurisdiction was disbelieved, and it had been demonstrated that High Courts were inaccessible and expensive fora which led to a denial of rights. ${ }^{10}$

Therefore, settling on the (revamped) children's courts as the first avenue for dispute resolution and adjudication, as well as for the fulfilment of the primary functions related to adoption, placement in foster care, welfare enquiries into children's care and protection needs, and so forth, the SALRC then drafted a vastly revamped role for the children's court, expanding not only its jurisdictional competence but also the array of interventions, orders and functions it would fulfil. Much of this latter line of reasoning has survived the parliamentary process, and produced a series of new functions and capabilities for children's courts. A full discussion lies beyond the scope of this article. ${ }^{11}$

But the core jurisdictional proposals of the SALRC changed shape and hue quite dramatically even before the parliamentary process which led to the finalisation of the Children's Act 38 of $2005 .{ }^{12}$ In fact, the first round of amendments was effected by the Department of Social Development before

9 SALC Project 110 Discussion Paper on the Review of the Child Care Act 2001:11541156 and SALC Project 110 Report on the Review of the Child Care Act 2002.

10 SALRC Report on the Review of the Child Care Act 2002 vol. 2:307-309.

11 Gallinetti 2007:4-11; Skelton and Proudlock 2007:1-14 in general.

12 See Skelton and Proudlock 2007 for a brief overview. 
the Bill produced by the SALRC entered the parliamentary process. As regards main characteristics of the changes brought about to the SALRC proposals, first, the two-tier court structure, which in effect sought to create a 'regional level' jurisdiction in child law matters, was dropped. In its stead, a single tier system for all matters related to the Act, irrespective of complexity or nature, was promoted, and this would comprise, as in the past, the children's court situated at magistrate's court level. (As mentioned, the extended role, functions and, above all, powers of the children's court remained more or less intact, however.) Reportedly, the objections to the two-tier structure were raised by the Department of Justice and Constitutional Development.

Secondly, the ongoing lack of progress, by that stage indicative of a complete policy failure, relating to the development of the pilot Family Courts as a means of transforming the black divorce courts (as they were widely known), left the legislator with little choice but to retain the references to High Courts as well as the mentioned description of 'divorce courts'. This was in lieu of the ideal, which was to remove High Court jurisdiction altogether in children's matters, including those incidental to parental separation. This position pertains in the Children's Act that was finally passed.

Thirdly, a direct intervention during the parliamentary process before the Portfolio Committee of Social Development by the Portfolio Committee on Justice and Constitutional Development saw a hard-line stance being taken on the proposed dilution (or elimination) of High Court role in the jurisdictional conundrum. The retention of guardianship as the exclusive preserve of the High Court was the result of this. The logic and reasoning of this insistence are none too clear, other than the argument that guardianship matters involve (at times) status-changing events such as marriage, or removal of the child from the Republic, or encumbrance and alienation of the child's property - and that these matters are too 'serious' to be dealt with by a lower court (a mere creature of statute). Civil society objected rigorously against the illogical ${ }^{13}$ and confusing position, but to no avail.

Now, a schizophrenic position prevails. This rests to a large extent on the interplay between the following sections:

- Section 1(4) which reads that "any proceedings arising out of the application of the Administration Amendment Act 9 of 1929, the Divorce Act, the Maintenance Act, the Domestic Violence Act 166 of 1998 and the Recognition of Customary Marriages Act, 1998 (Act 120 of 1998) insofar as these Acts relate to children, may not be dealt with in the children's court". ${ }^{14}$ (This section was evidently inserted while the Bill was discussed in Parliament, at the insistence of the Justice sector). This section

13 Illogical, given the fact that the children's court is empowered to perform comparably drastic steps in relation to parental powers such as the complete severance thereof when approving an adoption.

14 Note that the lack of reference to Act numbers and the year of passage in respect of the Divorce Act and the Maintenance Act are reproduced from the original of section 1(4) of the Children's Act. Other Acts referred to in this section bear numbers and dates. 
appears to underscore the position that divorce (including those aspects relating to the allocation of parental responsibilities for children), domestic violence (for which dedicated courts are also in operation), and recovery of maintenance (similarly, separate courts exist for applications under the Maintenance Act 99 of 1998) do not fall within the remit of the children's court, even if the wide powers accorded this court in Chapter 4 suggest otherwise. ${ }^{15}$

- $\quad$ Section 22(7) which provides that only a High Court may confirm, amend or terminate a parental responsibilities and rights agreement that relates to guardianship of a child.

- Section 24(1) which states that "any person having an interest in the care, well-being and development of a child may apply to the High Court" for an order granting guardianship to the applicant.

- $\quad$ Section 29, which provides for the jurisdiction of the court, including High Courts, being founded in the court in whose jurisdictional area the child is ordinarily resident.

- Section 45(3) (placed in the children's court chapter) which confirms, in what purports to be plain language, the exclusive jurisdiction of the High Courts AND divorce courts over eight listed legal issues, starting with guardianship, pending the establishment of family courts by an Act of Parliament. ${ }^{16}$

The schizophrenic position that emerges from the above position lies in the fact that most matters affecting parental responsibilities and rights are in contradictory fashion accorded children's courts and, at the same time, some are reserved exclusively for other courts. Section 1(4) is especially problematic insofar as it purports to bar a children's court from dealing with domestic violence and maintenance, which are crucial issues in the sphere of child care and protection.

\section{The JRCAA}

The new jurisdiction of the Regional Courts is rather inelegantly set out in the $J R C A A$. The JRCAA repeals the Administration Amendment Act 9 of 1929, the Act which had formerly established 'Black Administration Courts' and which

15 It is notable, perhaps, that the courts referred to in section 1(4) fall under the Department of Justice and Constitutional Development. The children's court is something of a hybrid: staffed by magistrates, children's courts have from time to time been regarded as 'belonging' to Social Development. This became manifest when the amendments effected to the Child Care Act 74/1983 in 1996 to give effect to children's constitutional right to legal representation in the children's court was ultimately never promulgated, due to a dispute between Departments about which Department would bear the costs of such legal representation.

16 It is suggested that the introduction of the JRCAA does not 'establish family courts by an Act of Parliament' as provided for in the Children's Act, and cannot be construed as fulfilling the suspensive condition in the Children's Act created by section 45(3). See section 5 below for further discussion of this aspect. 
had been responsible for segregated justice in respect of a range of divorce disputes and in legal matters related to the administration of deceased estates of Black persons. ${ }^{17}$ The need to dispense finally with racially segregated courts cannot be faulted.

Of relevance to this discussion is section 29(1B) of the $J R C A A^{18}$ which provides as follows, amending section 29 of the Magistrates' Court Act, 1944: ${ }^{19}$

(1B) (a) A court for a regional division, in respect of causes of action, shall, subject to section $28(1 \mathrm{~A})$, have jurisdiction to hear and determine suits relating to the nullity of a marriage or a civil union and relating to divorce between persons and to decide upon any question arising therefrom, and to hear any matter and grant any order provided for in terms of the Recognition of Customary Marriages Act, 1998 (Act No. 120 of 1998).

(b) A court for a regional division hearing a matter referred to paragraph

(a) shall have the same jurisdiction as any High Court in relation to such a matter.

In the transitional provisions (section 9 of the $J R C A A$ ), it is made clear that the old 'black divorce courts' set up under the Black Administration Act, 1929 (subsequently the Administration Amendment Act), are no more: they now become 'a court of the regional division designated by the Minister'. Officers of such courts are now also holders of the rank of magistrate of the regional division. Any reference in any law to a 'divorce court' is, according to section 9(5), "deemed to be a reference to a court of a regional division".

The first question that arises is precisely which legal matters are affected by the 'extension of regional court jurisdiction'. For this, the wording (ipsissima verba) of the quoted section is the first point of departure: it refers to nullity of marriages and civil unions, divorce between persons and decisions from any questions there from. Any order possible under the Recognition of Customary Marriages Act (RCMA) (including those related to matrimonial property regimes whether upon dissolution of a marriage or not) are obviously included by the express wording of the section.

Divorce ordinarily refers to the act of dissolution of the marriage between the adult parties. The Divorce Act 70 of 1979 does not define divorce. However, 'divorce action' is defined in the Divorce Act to mean in the first instance an "action by which a decree of divorce or other relief in connection therewith

17 Moseneke and ors v Master of the High Court and ors 2001 (2) BCLR 103 (CC).

18 The extension (creation?) of a Regional Courts' civil jurisdiction in matters sounding in money in claims to the value of R300.000 is also substantially affected by the $J R C A A$. However, the relevant provisions and their effect will not be dealt with in this article.

19 The new subsection (d) provides that: "Any person who has been appointed as a Family Advocate or Family Counsellor under the Mediation in Certain Divorce Matters Act, 1987 (Act No. 24 of 1987), shall be deemed to have also been appointed in respect of any court for a regional division having jurisdiction in the area for which he or she has been so appointed". 
is applied for". ${ }^{20}$ What this relief may comprise is not spelt out. Admittedly, the definition of 'divorce action' continues to include "an application pendente lite for an interdict or for the interim custody or for access to a minor child of the marriage concerned or for the payment of maintenance". But note the reference to interim custody or access which forms part of this definition. The crisp question is whether the finalisation of custody or access (as they were termed before the parental responsibilities and rights regime of the Children's Act 58 of 2005 gained the force of law) is necessarily or by implication part of a divorce action.

Shafer's Family Law Service argues that a divorce action includes not only the decree of divorce or other ancillary relief in connection therewith but also applications pendente lite for an interdict, maintenance or for the custody of (care) or access to (contact with) the minor child. ${ }^{21}$ Schafer does not appear to make anything of the word "interim" which is contained in the wording of the Divorce Act regarding the meaning of a divorce action. Nor do Van Heerden et al. address this point. ${ }^{22}$

De Jong clearly implies that final decisions concerning the division of parental responsibilities and rights are part and parcel of the divorce order, and argues this from the perspective of the protection of the rights of the child. ${ }^{23}$ In the context of her discussion of a purported 'divorce' of 'divorce' from the allocation of parental responsibilities and rights, a decision in which the child's right to contact was left altogether unresolved and to be dealt with at a later stage, thus compromising the best interests of the child, this $a b$ initio stance may seem to make sense. ${ }^{24}$ Certainly this is how for decades the South African family law practice has functioned, treating the finalisation of parental rights and responsibilities allocations as part and parcel of divorce, to be effected by the High Court having jurisdiction. While this may be in the children's best interests generally, it is submitted that it is not always in the best interests of children that parental rights and responsibilities be tied to disputes about other aspects of the divorce, and that especially disputes about the division of property may spill over and affect the determination of care and contact issues - as indeed frequently happens where children become pawns in a larger struggle. There are good reasons for opting for a position that aspects of a divorce decision regarding parental responsibilities and rights may be separated from other aspects.

However, as will become evident, the real question that arises is whether variations, terminations and suspensions of decisions relating to children made at divorce continue after the finalisation of the divorce order itself to be

20 See the definitions section (section1).

21 Issue 521, F54 (Butterworth and Co).

22 Van Heerden et al.1999:510, 514-524 and 640-643.

23 For contrary (earlier) case law which insinuates that care matters need not necessarily form part of the decree of divorce, and that the divorce action can be disposed of and the care issues dealt with at a later stage, see Kastan $v$ Kastan 1985 (3) SA 236(C); Zorbas v Zorbas 19873 SA 436 (W); Ex Parte Critchfield 1999 3 SA $132(\mathrm{~W})$.

24 De Jong and Kruger 2010. 
"matters arising there from"? The answer to this is crucial to the interpretation of the jurisdictional ambit of the $R C A A$, as such post-divorce variations are a frequent occurrence.

The JRCAA, too, seems to 'divorce' children from divorce: no mention is made at all of the consequences of divorce relating to children, such as assignment of parental responsibilities and rights, nor the all-important issue of guardianship. Possibly, we are supposed to infer that responsibility for children and their maintenance, care and contact are 'questions arising' from divorce - for this has always been the case in South African divorce law, albeit rather unsystematically. We have an entire court structure - maintenance courts, which are district courts and not regional courts - devoted to the very purpose of dealing with maintenance, including maintenance arising from divorce. But technically, jurisdiction for variation of care and contact orders (and guardianship) would lie with High Courts which were seized with the initial order as a rule, ${ }^{25}$ this position was standard before the introduction of jurisdictional competence to decide upon care, and contact was expressly extended to the children's court by the Children's Act.

Therefore, it would have been helpful to spell out precisely what is meant by "questions arising from divorce" in the JRCAA, especially as the Act postdates both the passage and the coming into operation of the Children's Act's new rules on parental responsibilities and rights. ${ }^{26}$ Moreover, the Children's Act itself does not assist in resolving the issue as to whether the children's court can vary care and contact orders previously part of a divorce order made by the High Court. Section 45(3), which deals with exclusive jurisdictional competence of High Courts and Divorce Courts (pending the establishment by an Act of Parliament of Family Courts) in the eight listed areas, is silent as to whether care and contact arrangements resulting from divorce are the sole purview of Divorce Courts and High Courts.

In theory, the Regional Court, which now (having the same divorce jurisdiction as the High Court) deals with divorce, need not also immediately deal with aspects of care and contact - and these could be referred to a children's court for adjudication - provided that the children's court involvement does not concern the allocation or restriction of guardianship, and deals only with the remaining aspects of care and contact. Likewise, as was envisaged, variation, rescission and termination of a previously granted care and contact order could be dealt with in the children's court under previously quoted sections of the Children's Act (e.g. section 28(1) deals with applications for termination, suspension, etc. of parental responsibilities and rights), as the SALRC clearly proposed. Hence, the prospect does exist of an articulation 'downwards' between Regional Court and children's court (i.e. the children's court varying or amending interim care and contact orders previously given by a Regional Court).

25 Van Heerden et al.1999:640-643.

26 Certain sections came into operation on 1 July 2007, including most of the chapter on parental responsibilities and rights (Chapter 3 ). 
An unexpected result of the definition of a 'divorce court' in section 1 of the Children's Act, which links the reference to a divorce court in the body of the legislation to the courts established under the Black Administration Act, is that those courts have been abolished with the promulgation of the JRCAA. Hence, where the JRCAA refers in section 9(5) to "a reference in any law to a "divorce court"' being deemed to be a reference to a court of a regional division, that phrase "reference in any law" cannot mean the references to divorce courts in the Children's Act, as these no longer exist due to the coming into operation of the JRCAA. (It must be remembered that the geographical jurisdiction of the old black divorce courts differed markedly from the Regional Courts' geographical jurisdiction, and the new civil regional courts are hence not the automatic successors of the former black divorce courts).

It must be pointed out, when considering the evidently confusing position that now prevails, that the JRCAA was passed at a time when the Children's Act had already been completed, and was partly in operation. The Children's Act is not mentioned at all in the JRCAA, despite the array of other statutes in the family law arena which do receive express mention. The failure to consider the interface with the Children's Act leads to some of the consequences discussed next.

\section{Guardianship: Which court has jurisdiction?}

It is fairly trite that the standard version propagated in family law is that the High Court retained guardianship jurisdiction in the aftermath of the deliberations on the Children's Act. ${ }^{27}$ This is clear from a plain reading of, for instance, section 24(1) which provides for the application to the High Court for an order granting guardianship of a child, from sections $22(7)$ and $45(3) .{ }^{28}$ It was also the deliberate result of interventions in Parliament from the Justice sector, as noted previously in this article. But is this still the case?

First, it is the reference to 'a divorce court in divorce matters' which gives rise to the potentially confusing position that such court may now be the Regional Court by virtue of section 29(1B) of the JRCAA, which confers jurisdiction in "divorce and matters arising there from". Hence, when dealing with guardianship in a divorce action, which is almost inevitable insofar as guardianship is a component of parental responsibilities and rights, it seems that the JRCAA now confers jurisdiction on the Regional Court, thus overriding the earlier award of exclusive jurisdiction to the High Court in the Children's

27 See, for instance, Heaton 2007:3-9.

28 Even this seemingly clear position becomes a little murkier when regard is given to section 28 of the Children's Act, which deals with termination, extension, suspension or restriction of parental responsibilities and rights. This latter application (by a coholder of parental responsibilities and rights, by any other person having a sufficient interest in the care, protection, well-being or development of the child; by the child in the child's interest by any other person; by a family advocate or the representative of any organ of state (section 27(3)) may be made to a High Court, a divorce court in a divorce matter or a children's court. Nowhere is it expressly stated that only a High Court may restrict or suspend guardianship. This has to be 'read in'. 
Act. As to whether applications for termination, extension, suspension or restrictions upon guardianship arising from divorce now belong in the lower courts, specifically the Regional Court, ${ }^{29}$ it is submitted that the answer is affirmative, and that the intention of the JRCAA was precisely to move all aspects of divorce and its consequences to a lower level in the court structure, and thereby to create a parallel jurisdictional competence which would extend to all facets of the potential relief sought. Supporting this reasoning is the fact that there is no evident scope to transfer a matter from Regional Court to High Court, should the award of guardianship emerge as a contested issue on its own during the course of divorce proceedings instituted in the Regional Court.

Secondly, the question arises as to which court would enjoy jurisdiction in respect of guardianship where it is not incidental to divorce. It seems that the plain prescriptive language of the Children's Act, coupled with the limitation of the JRCAA to "matters arising from divorce", leaves no other interpretation than that the High Court retains exclusive jurisdiction. This would mean, for instance, that an application for guardianship of an HIV/Aids orphan, which is unlinked to divorce, must remain a High Court matter - i.e. the most expensive and least geographically accessible option. ${ }^{30}$ This is paradoxical to say the least.

Thirdly, the inherent jurisdiction of the High Court regarding guardianship ${ }^{31}$ is unaltered by the recent statutory changes. Hence, it remains open to any party to approach the High Court on issues related to its inherent jurisdiction, which cannot be devolved upon mere 'creatures of statute', viz. the Regional Courts.

Four, the effect which conferring formerly High Court jurisdiction on a lower court has upon the established hierarchy is unclear. In Ntuli v Zulu 20051 SA $45(\mathrm{~N})$ the court found that the black divorce courts which operated under the Administration Act had the status of inferior courts and, as such, proceedings held in these courts were subject to review by the High Court. Although the civil Regional Court, as referred to in the JRCAA, is not a direct successor to the black divorce courts, it may be so that decisions on guardianship, care or contact of the courts now imbued with jurisdiction by the JRCAA can

29 The general view has been that the wording of section 28 of the Children's Act allows variation of (e.g.) care and contact orders by a range of courts, which theoretically empowers a children's court to interfere with a prior High Court order in which the details of care, residence, etc. were spelt out. Skelton (Boezaart 2010:83), for instance, argues that the section seems to offer a choice of forum, although she continues to advise that given the restrictive application of section 1(4) to matters arising from a divorce, which remain the jurisdiction of the High Court (in terms of the Children's Act), the original court should be approached when variation, etc. is sought. Added to this insight, now, is the JRCAA which confers identical jurisdiction on the Regional Courts, so that her view must be supplemented with the further proviso that now a High Court order can be amended in the Regional Court (but probably not in the children's court).

30 See Ex Parte Sibisi (case 2115/10 KZN High Court), unreported, which concerned an application for guardianship of an orphan. At paragraph 14 the court recommended legislative amendment to clarify the jurisdictional issues around guardianship.

31 See, in general, Van Heerden et al.1999:500-501. 
nevertheless be reviewed by a High Court, as well as (in addition to) being brought before High Courts on appeal.

\section{When is the Regional Court to be a court of first instance in family law matters, in contrast to the children's court, and specifically with respect to parental responsibilities and rights?}

One reading of the JRCAA entails that the Regional Court is a court of first instance when any aspect of parental rights and responsibilities is coupled to 'a divorce action'. This seems to have been the intention of the legislature in expressly extending divorce jurisdiction, with ancillary relief, to Regional Courts.

So, too, it is arguable that a Regional Court may be approached in the first instance for the registration of a parenting plan (and possibly a parental responsibilities and rights agreement). Parenting plans, in particular, may arise as a postscript to divorce, where co-holders of parental responsibilities and rights are "experiencing difficulties in exercising their responsibilities and rights" (section 34(2) of the Children's Act). The (Regional) court which had granted the divorce would undoubtedly be competent thereafter to permit variations of the order via a subsequent parenting plan.

However, neither section 34 of the Children's Act nor regulations 7, 9 and 10 nor the Forms refer expressly in this instance to a 'divorce court'. While section 34 refers only to "a court", regulation $7(3)$ mentions that where the allocation of guardianship occurs in a parental responsibility and rights agreement, the agreement must be made an order of the High Court; regulation 7(5) refers to filing of the agreement with the Family Advocate, children's court or High Court. Regulation 9(3) is similarly worded in relation to filing of parenting plans. The competence of Regional Courts to register plans and agreements is thus insufficiently laid out in law. The question as to whether Regional Courts may be approached as registrars of first instance has considerable practical implications, as these courts will need to know whether the necessary filing and administrative systems are required to be established or not.

The above omissions arise from the fact that the model proposed by the SALRC was not adopted in the version of the Children's Act adopted by Parliament; hence, it was not envisaged, at the time of drafting the regulations, that courts of regional stature would be involved in divorce litigation as courts of first instance. Therefore the new provisions enhancing the allocation and exercise of parental responsibilities and rights were not made applicable to Regional Courts. 


\section{Hague abduction matters and relocation disputes}

Hague abduction matters and relocation disputes have traditionally been the preserve of the High Courts. Relocation of a parent who is a holder of parental responsibilities and rights outside the borders of South Africa relates to "removal of the child from the Republic", which is expressly an incidence of guardianship (section 18 of the Children's Act), which makes this a High Court function. Hague abduction matters ${ }^{32}$ may or may not relate to a prior divorce, depending on the prior relationship between the disputing parents who have access rights that have been disturbed by the wrongful retention or abduction. Section 45(3) of the Children's Act makes it clear, as mentioned, that "pending the establishment of family courts by an act of Parliament, High Courts and Divorce Courts have exclusive jurisdiction" over departure, removal and abduction issues. However, as noted earlier, the divorce courts alluded to in the Children's Act are defined in section 1 as those courts established under the Administration Amendment Act 9 of 1929 which, in turn, have now been abolished. It is unclear, therefore, if the new jurisdiction of the Regional Courts extends to Hague matters and to removal/relocation applications. At face value, it would seem that it does not.

This view is supported by the text of the JRCAA, which fails to mention the Hague Convention and international child abduction, even though a reference is made to the applicability of the Mediation in Certain Divorce Matters Act and the role of the Family Advocate in Regional Court divorces. This is potentially relevant as the body set up under this Act - the Office of the Family Advocate - is the custodian of the Hague Abduction Convention, and the Chief Family Advocate is the Central Authority designated under that Convention. The various offices of the Family Advocate have built up vast experience in pursuing and assisting with Hague claims since South Africa's ratification of the treaty in 1997. But unless the JRCAA can be stretched to accommodate Hague abduction cases that arise from a prior divorce - for instance, a divorce previously dealt with in that same Regional Court acting as a court of first instance - it would appear that the exclusive preserve of the High Court in Hague cases remains untouched. Certainly, it would appear difficult to found Regional Court jurisdiction, given the lack of a reference to Hague matters in the JRCAA, given the express reference to High Court jurisdiction in chapter 17 of the Children's Act (the international child abduction chapter), and in view of the reality that Hague matters do not necessarily relate to divorce (e.g. when access rights of unmarried parents are at issue). Moreover, Hague jurisdiction may not even relate to a divorce that has occurred in this country. If, for instance, the divorce in respect of which a Hague application relates had been finalised in Germany or Canada, our High Courts would not have had jurisdiction 'arising from divorce' in the first place due to the usual laws of domicile, rendering it doubtful whether the JRCAA can then devolve that nonexistent jurisdiction to inferior courts (which are creatures of statute).

32 Matters concerning the 1980 Hague Convention on the Civil Aspects of International Child Abduction, now incorporated domestically in Chapter 17 of the Children's Act, and attached in full as a schedule to the Act. 
Relocation jurisdiction may also raise related problems. It is not inconceivable that relocation applications may arise between unmarried parents, who share parental responsibilities and rights as a result of either the automatic acquisition of parental responsibilities and rights in terms of section 21 of the Children's Act, or as a result of an agreement concluded in terms of section 22 of this Act. Divorce is and was not an issue, and hence the jurisdiction of the Regional Court cannot arise. High Court jurisdiction remains the only option, according to the wording of the Children's Act. Surrogacy, of course, is even less related to divorce and since Chapter 19 of the Children's Act confers jurisdiction to approve surrogacy agreements only on High Courts, any potential role for Regional Courts cannot arise.

It is therefore submitted that the JRCAA did not intend to confer jurisdiction on Regional Courts in any of these matters, since it cannot logically be accepted that the Regional Court's jurisdiction on international child abduction and relocation is reserved only for disputes involving the previously married. In addition, allocating different courts for the previously married and previously unmarried would constitute a clear violation of the constitutional right to nondiscrimination on the basis of marital status. Therefore, any Hague or relocation matter arising from a divorce, even if previously finalised in a Regional Court, may have to be set down in a High Court for adjudication.

\section{The positive, the less positive and recommendations for reform}

It seems almost contradictory to complain that the largely lower court-based model envisaged by the SALRC has in fact almost come to fruition via the $J R C A A$, albeit rather unexpectedly, and by a route undebated by civil society. Hence, the major achievement of the JRCAA is that almost all family law matters must now be dealt with at regional and district court level, which is more affordable and geographically accessible than the High Court. This accommodates one key overarching aim of the law reform process, namely to render justice more accessible where children are concerned. In addition, the black divorce courts are a creature of the past, and have been abolished. Finally, the stillborn concept of pilot Family Courts, which did not make much progress in the decade of their existence, has finally been laid to rest. These three aspects of the JRCAA can be regarded as being positive.

However, a less positive feature of the JRCAA and the model it creates is that the vision is a partial one. For instance, there is clearly no articulation between the district children's court and the Regional Court, as was envisaged by the SALRC for instances in which a more complicated issue emerges, or where an appeal is noted. ${ }^{33}$ Instead of articulation, two compartmentalised court structures, viz. children's courts and Regional Courts, seem to be jurisdictionally competent in overlapping ways. The relationship between them is murky, at best.

33 SALRC Report on the Review of the Child Care Act (2002) paragraph 22.3. 
The articulation between the Regional Courts and the High Court is also somewhat illogical, as evidenced by the fact that the latter is, according to case law, a court of review of the former, as well as a court of appeal and, in some instances, a court of concurrent jurisdiction. That forum shopping may emerge is a distinct possibility.

The lack of clarity on guardianship has not been resolved in the wording of the JRCAA, and the Children's Act's evident distinction between 'divorce courts' (now defunct) and High Courts (in whose domain alone guardianship must fall) becomes ever more difficult to justify logically and consistently. Indeed, the $J R C A A$ does not mention or refer to the provisions of the Children's Act, which poses a great dilemma. Calls for amendment of the Children's Act to clarify the guardianship provisions have already begun to emerge in the courts. ${ }^{34}$

It is less than optimal that the JRCAA fails to deal properly with all of the dimensions of family law practice - including parental responsibility and rights agreements, parenting plans, relocation disputes, Hague cases and surrogacy, to mention but a few. The JRCAA is premised solely on the aftermath of divorce, which shows a narrow understanding of family law, and negates the tremendous steps that have been taken in developing a more realistic understanding of 'family' which includes unmarried partners and other stakeholders in parental responsibilities and rights pertaining to children. ${ }^{35}$

Another facet of the JRCAA that represents a less positive dimension emerges from the way in which implementation has been dealt with. Some years ago a small cohort of magistrates were given family law training with the idea that they might become the family law/civil law specialists of the pilot Family Courts, as they then seemed to be developing. That training is long since of little use, and no additional training of substance has been noted. Even training on the Children's Act for justice officials has been rather lacking, with few efforts having been made to prepare lower court officials for implementation even three years after the promulgation of the first parts of the Act.

The new arrangements in the JRCAA were put into operation on 9 August 2010 without any 'back up' in the form of skilled personnel, training, or systems. Although Rules were finalised and promulgated in October 2010, most people were totally unaware of the widespread promulgation of the Act that was about to occur unexpectedly. ${ }^{36}$ Ultimately, family law academics, teachers and practitioners will all experience the JRCAA as disempowering: it negates years of good work (e.g. of the SALRC, the Parliamentary Portfolio Committee on Social Development that engaged with the Children's Act and its Regulations, and so forth) that has gone into reshaping and harmonising family and child law processes. ${ }^{37}$ The main objective of the hasty

34 See Ex parte Sibisi (note 30 above).

35 See, for instance, Sloth-Nielsen and Van Heerden 2003.

36 Discussion with a senior Justice Department Official, September 2010, who noted that during the last week of September, hasty arrangements were being made to send regional courts magistrates for training.

37 See Sloth-Nielsen and Du Toit 2008 for a collection of papers from the first 10 years of annual family law conferences convened among academics, practitioners, Family 
implementation of the JRCAA without prior infrastructure, training and public preparation seems to have taken place due to the goal of enabling Regional Court magistrates to gain civil experience so that they qualify for judicial appointment. In the short term, this does a great disservice to family law and children caught up in legal processes.

The implementation of the JRCAA leaves a legacy of confusion, which will lead to a multitude of complications, not the least of which is working out what matters arising from divorce are now the preserve of the Regional Courts. Whereas the clear implication of the Children's Act (section 28) is that variations, suspensions and terminations of parental responsibilities and rights arrangements can be dealt with at children's court level, this might not actually happen. Children's court magistrates, fearful of overstepping their statutory mandate, might decline to review parental responsibilities and rights allocations arising out of divorces previously granted by Regional Courts, on the grounds that only the hierarchically higher court has the competency to adjudicate. The wide powers awarded the children's court, the most accessible forum for ordinary people, will then become dead letters.

It is therefore recommended that legislative reform is urgently required: article 1(4) of the Children's Act must be deleted in its entirety, and the sections of the Children's Act which reserve guardianship jurisdiction only for High Courts removed as having been superceded by the JRCAA. The references in the Children's Act to a 'divorce court' are also now obsolete and can safely be deleted. In place of references to divorce courts, the Children's Act can clarify that Regional Courts enjoy the same jurisdiction as High Courts, and spell out whether this extends to relocation issues as well as to Hague abduction applications. The JRCAA should also be amended to remove the phrase "matters arising from divorce" as part of the founding jurisdiction it purports to confer, and to explain how termination, variations and amendments of parental rights and responsibilities are to occur, as well as to provide for the jurisdiction of these courts where unmarried parents contest, for instance, guardianship. The regulations will need to be adapted to empower Regional Courts to register parenting plans, or at least indicate where parenting plans formulated during divorce proceedings in Regional Courts are supposed to be lodged.

Advocates and government officials to share practice and policy developments relating to child and family law. 


\section{Bibliography}

BOEZAART T

2009. Child law in South Africa. Cape Town: Juta.

\section{BoEzAart T}

2009. Child law, the child and South African private law. In $\mathrm{T}$ Boezaart (ed) 2009: 3-37.

\section{BUDLENDER D}

1998. The Pilot Family Courts: Doing something with nothing. Occasional paper, Law, Race and Gender Project, University of Cape Town.

Burman S, Dingle E and Glasser N 2000. The new Family Court in action: An initial assessment. South African Law Journal 117(1):111-124.

Chaskalson J and De Jong I 2002. Consulting 'Family Courts in South Africa: Draft Discussion Document'. Department of Justice and Constitutional Development Business Unit: Court Services, Family Court Task Team (15 November 2002).

ClaRK, B

1998. Family law service (with looseleaf updates) Lexis Nexus:Durban.

Davel CJ and Skelton AM (eds) 2007. Commentary on the Children's Act. Cape Town: Juta.

De Jong M and Kruger H 2010. The postponement and separation of children's issues upon divorce - quick relief or a glaring mistake? $K v K 20085$ SA 431 (W). Tydskrif vir Hedendaagse RomeinsHollandse Reg 73:1-5.

\section{GallinetTI J}

2007. The Children's Court. In CJ Davel and AM Skelton (eds) 2007:4:1-4:37.
Heaton J

2007. Parental responsibilities and rights. In CJ Davel and AM Skelton (eds) 2007:3:1- 3:45.

\section{SKELTON A}

2009. Parental responsibilities and rights. In T Boezaart (ed) 2009:62-92

\section{Skelton A and Proudlock P}

2007. Interpretation, objects, application and implementation of the Children's Act. In CJ Davel and AM Skelton (eds) 2007:1:1-1:14.

Skelton A, Carnelly M, Human S,

Robinson J AND SMith B 2010. Family law in South Africa. Oxford: Oxford University Press.

\section{Sloth-Nielsen J and Du Toit Z} 2008. Trials and tribulations, trends and triumphs. Cape Town: Juta.

Sloth-Nielsen J and Van Heerden B 2003. The Constitutional family: Developments in South African family law and jurisprudence under the 1996 Constitution. International Journal of Law, Policy and the Family 17(2):121-146.

\section{South African Law Commission}

(PROJeCt 110)

2001. Discussion Paper on the Review of the Child Care Act. Pretoria: South African Law Commission.

2002. Report on the Review of the Child Care Act. Pretoria: South African Law Commission.

Van Heerden B, Cockrell A,

Kneightley R, Heaton J, Clarke B,

Sinclair JD and Mosikatsana T

1999. Boberg's Law of persons and the family. Cape Town: Juta. 